\title{
Advantages of N-Type Hydrogenated Microcrystalline Silicon Oxide Films for Micromorph Silicon Solar Cells
}

\author{
Amornrat Limmanee, Songkiate Kittisontirak, Sorapong Inthisang, \\ Taweewat Krajangsang, Jaran Sritharathikhun, and Kobsak Sriprapha \\ Solar Energy Technology Laboratory, National Electronics and Computer Technology Center, National Science and Technology \\ Development Agency, 112 Thailand Science Park, Phahonyothin Road, Klong 1, Klong Luang, Pathum Thani 12120, Thailand
}

Correspondence should be addressed to Amornrat Limmanee; amornrat.limmanee@nectec.or.th

Received 9 May 2013; Revised 30 May 2013; Accepted 30 May 2013

Academic Editor: Leonardo Palmisano

Copyright (C) 2013 Amornrat Limmanee et al. This is an open access article distributed under the Creative Commons Attribution License, which permits unrestricted use, distribution, and reproduction in any medium, provided the original work is properly cited.

\begin{abstract}
We report on the development and application of $\mathrm{n}$-type hydrogenated microcrystalline silicon oxide films ( $\mathrm{n} \mu \mathrm{c}-\mathrm{SiO}: \mathrm{H})$ in hydrogenated amorphous silicon oxide/hydrogenated microcrystalline silicon (a-SiO:H/ $\mu \mathrm{c}-\mathrm{Si}: \mathrm{H})$ micromorph solar cells. The $\mathrm{n}$ $\mu \mathrm{c}$-SiO:H films with high optical bandgap and low refractive index could be obtained when a ratio of carbon dioxide $\left(\mathrm{CO}_{2}\right)$ to silane $\left(\mathrm{SiH}_{4}\right)$ flow rate was raised; however, a trade-off against electrical property was observed. We applied the $\mathrm{n} \mu \mathrm{c}-\mathrm{SiO}: \mathrm{H}$ films in the top a-SiO:H cell and investigated the changes in cell performance with respect to the electrical and optical properties of the films. It was found that all photovoltaic parameters of the micromorph silicon solar cells using the $\mathrm{n}$ top $\mu \mathrm{c}$-SiO:H layer enhanced with increasing the $\mathrm{CO}_{2} / \mathrm{SiH}_{4}$ ratio up to 0.23 , where the highest initial cell efficiency of $10.7 \%$ was achieved. The enhancement of the open circuit voltage $\left(V_{\text {oc }}\right)$ was likely to be due to a reduction of reverse bias at subcell connection $-\mathrm{n}$ top/p bottom interface-and a better tunnel recombination junction contributed to the improvement in the fill factor (FF). Furthermore, the quantum efficiency $(\mathrm{QE})$ results also have demonstrated intermediate-reflector function of the $\mathrm{n} \mu \mathrm{c}-\mathrm{SiO}: \mathrm{H}$ films.
\end{abstract}

\section{Introduction}

Wide-bandgap silicon oxide based materials have been widely studied for thin film silicon solar cell applications because of their attractive optical and electrical properties [1-4]. Characterizations of boron doped hydrogenated amorphous and microcrystalline silicon oxide films (p a-SiO:H and $\mathrm{p} \mu \mathrm{c}-\mathrm{SiO}: \mathrm{H}$ ) and their applications as window layer of solar cells have been reported by many research groups $[5,6]$. $\mathrm{N}$-type a-SiO:H and $\mu \mathrm{c}-\mathrm{SiO}: \mathrm{H}$ films also have been developed and applied in single junction and multijunction thin film silicon solar cells [7-11]. However, most works focused on an intermediate-reflector function of the $\mathrm{n} \mu \mathrm{c}-\mathrm{SiO}: \mathrm{H}$ films in conventional a-Si:H/ $\mu \mathrm{c}-\mathrm{Si}: \mathrm{H}$ micromorph solar cells and paid little attention to their effects on junction connection and band diagram continuity [7-10]. Moreover, application of the $\mathrm{n} \mu \mathrm{c}-\mathrm{SiO}: \mathrm{H}$ films to a-SiO:H based solar cells has not yet been reported; thus there is still much room for further research.
Our group has been investigating the wide bandgap $\mathrm{SiO}: \mathrm{H}$ based materials and previously reported performance of the a-SiO:H based solar cells with single junction and multijunction structures-a-SiO:H, a-SiO:H/a-Si:H, and a$\mathrm{SiO}: \mathrm{H} / \mu \mathrm{c}-\mathrm{Si}: \mathrm{H}$ [12-15]. In this work, we focus on properties of the $\mathrm{n} \mu \mathrm{c}-\mathrm{SiO}: \mathrm{H}$ films and their appropriateness to the use as the $\mathrm{n}$ top layer in the a-SiO:H/ $\mu \mathrm{c}-\mathrm{Si}: \mathrm{H}$ micromorph silicon solar cells. Properties of the $\mathrm{n} \mu \mathrm{c}-\mathrm{SiO}: \mathrm{H}$ films are presented along with the performance of the micromorph silicon solar cells.

\section{Experimental Details}

2.1. Preparation of $n \mu c-S i O: H$ Films. $\mathrm{N} \mu c-S i O: H$ films have been prepared by very high frequency plasma enhanced chemical vapor deposition (60 MHz VHF-PECVD) technique. The gas sources were silane $\left(\mathrm{SiH}_{4}\right)$, hydrogen $\left(\mathrm{H}_{2}\right)$, and carbon dioxide $\left(\mathrm{CO}_{2}\right)$, and phosphine $\left(\mathrm{PH}_{3}\right)$ was employed 
as a doping source. For film characterizations, the $\mathrm{n} \mu \mathrm{c}$ $\mathrm{SiO}: \mathrm{H}$ films were deposited on Corning glass substrates at the deposition temperature of $180^{\circ} \mathrm{C}$, a plasma power of $70 \mathrm{~mW} / \mathrm{cm}^{2}$, deposition pressure of $0.5 \mathrm{Torr}, \mathrm{H}_{2} / \mathrm{SiH}_{4}$ ratio of $35, \mathrm{PH}_{3} / \mathrm{SiH}_{4}$ ratio of 0.38 , and $\mathrm{CO}_{2} / \mathrm{SiH}_{4}$ ratio in the range of $0 \sim 0.28$. The thickness of the films was kept at about $350 \mathrm{~nm}$, which was measured by step profilometer. The crystalline volume fraction $\left(X_{c}\right)$ of the $\mathrm{n} \mu \mathrm{c}-\mathrm{SiO}: \mathrm{H}$ films was estimated by Raman scattering experiment. The Raman scattering spectra of the $\mathrm{n} \mu \mathrm{c}-\mathrm{SiO}: \mathrm{H}$ films in the $400-$ $600 \mathrm{~cm}^{-1}$ region can be deconvoluted into three spectra. A peak distribution around $470-475 \mathrm{~cm}^{-1}$ is assigned to the transverse optical (TO) mode of amorphous silicon, whose corresponding integrated area is identified as $I(a)$. A sharp peak arising at around $519-522 \mathrm{~cm}^{-1}$ corresponds to the transverse optical vibrational mode of crystalline silicon, and the associated integrated area is identified as $I(c)$. And the intermediate component corresponding to a peak at around $506-510 \mathrm{~cm}^{-1}$ is identified as $I(b)$. The crystalline volume fraction is calculated by using the simplified empirical relation as follows [16]:

$$
X_{c}=\frac{[I(c)+I(b)]}{[I(a)+I(b)+I(c)]} \text {. }
$$

We have measured the absorption data $(\alpha)$ of the films at visible range by UV/Visible spectrophotometer. Due to the varying structure of the films from microcrystalline to amorphous phase, we avoided Tauc's plots, and to give a numerical presentation of the shift in the absorption spectra we determined $E_{04}$, that is, the energy corresponding to $\alpha=$ $10^{4} \mathrm{~cm}^{-1}$, as an indicator of relative optical bandgap $\left(E_{\mathrm{op}}\right)$. Refractive index $(n)$ spectra of the films were estimated by Spectroscopic Ellipsometry (SE) using Tauc-Lorentz model [17]. The dark conductivity $\left(\sigma_{d}\right)$ of the films was measured in a coplanar configuration with $\mathrm{Al}$ electrode at room temperature.

\subsection{Fabrication of a-SiO:H/Mc-Si:H Micromorph Silicon Solar} Cells. We have applied the $\mathrm{n} \mu \mathrm{c}-\mathrm{SiO}: \mathrm{H}$ films as the $\mathrm{n}$ top layer of the micromorph silicon solar cells with the structure of TCO glass/ZnO/p- $\mu \mathrm{c}-\mathrm{SiO}: \mathrm{H} / \mathrm{i}-\mathrm{a}-\mathrm{SiO}: \mathrm{H} / \mathrm{n}-\mu \mathrm{c}-$ $\mathrm{SiO}: \mathrm{H} / \mathrm{p}-\mu \mathrm{c}-\mathrm{SiO}: \mathrm{H} / \mathrm{i}-\mu \mathrm{c}-\mathrm{Si}: \mathrm{H} / \mathrm{n}-\mu \mathrm{c}-\mathrm{Si}: \mathrm{H} / \mathrm{ZnO} / \mathrm{Ag}$ (cell active area was $0.75 \mathrm{~cm}^{2}$ ). Note that absorber layer of the top cell was wide-bandgap a-SiO:H film, and $\mathrm{p} \mu \mathrm{c}-\mathrm{SiO}: \mathrm{H}$ films were used as p layer in both top and the bottom cells. There was no intermediate layer at the junction connection between the top and bottom cells. Thicknesses of the i top a-SiO:H and i bottom $\mu \mathrm{c}-\mathrm{Si}: \mathrm{H}$ layers were 400 and $1500 \mathrm{~nm}$, respectively. The $\mathrm{CO}_{2} / \mathrm{SiH}_{4}$ ratio for the $\mathrm{n}$ top layer deposition was varied from 0 to 0.28 , while other conditions in cell fabrication were kept as the same. The thickness of the $\mathrm{n}$ top layer was approximately $30 \mathrm{~nm}$. The current-voltage $(I-V)$ characteristics of the solar cells have been investigated under the standard testing conditions-AM1.5, $100 \mathrm{~mW} / \mathrm{cm}^{2}$, and $25^{\circ} \mathrm{C}$-in a Wacom solar simulator. Quantum efficiency (QE) of the solar cells also has been evaluated by spectral response measurements.

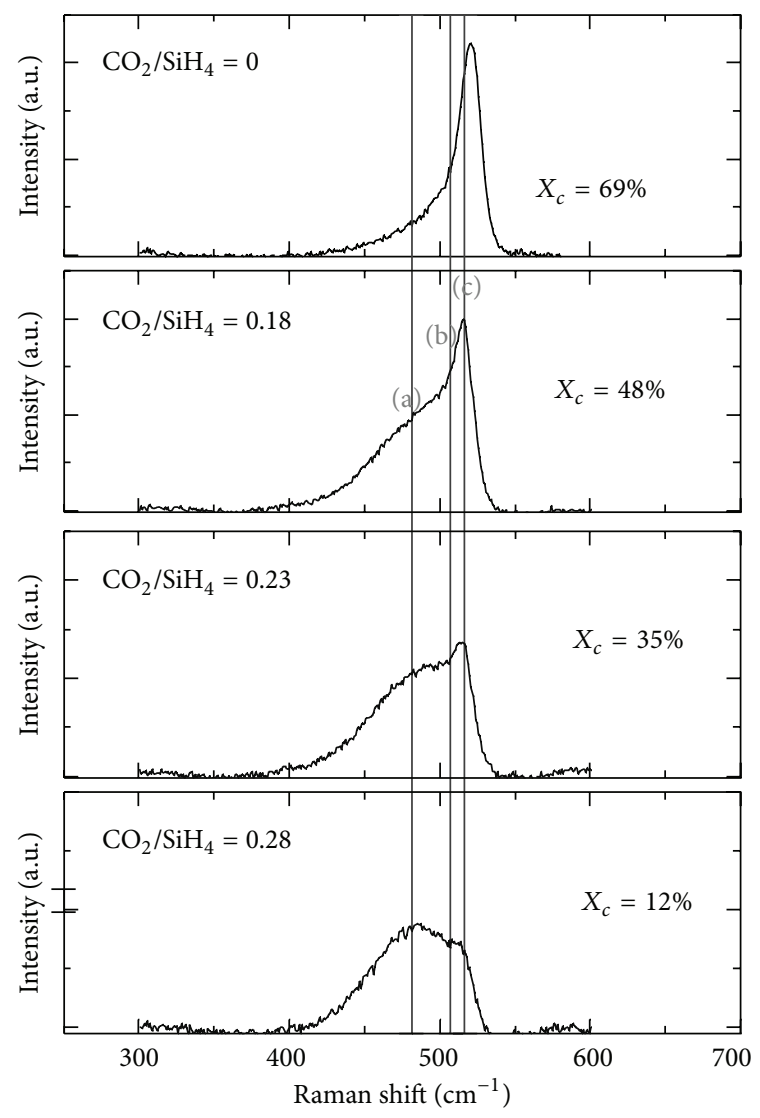

FIGURE 1: Raman spectra of $\mathrm{n} \mu \mathrm{c}$-SiO:H films deposited with different $\mathrm{CO}_{2} / \mathrm{SiH}_{2}$ ratios.

\section{Results and Discussion}

3.1. Properties of $n \mu c$-SiO:H Films. Figure 1 shows Raman spectra of the $\mathrm{n} \mu \mathrm{c}-\mathrm{SiO}: \mathrm{H}$ films deposited with different $\mathrm{CO}_{2} / \mathrm{SiH}_{4}$ ratios. It is obviously shown that the peak corresponding to crystalline phase, peak $(c)$, gradually decreased with increasing the $\mathrm{CO}_{2} / \mathrm{SiH}_{4}$ ratio, and the amorphous silicon (a) became a dominant phase at the ratio above 0.23 . With no $\mathrm{CO}_{2}$ addition the $X_{c}$ of the film was $69 \%$, decreasing to $12 \%$ at the $\mathrm{CO}_{2} / \mathrm{SiH}_{4}$ ratio of 0.28 .

The optical bandgap of the films tended to increase while the refractive index measured at the wavelength of $550 \mathrm{~nm}$ showed an opposite change when the $\mathrm{CO}_{2} / \mathrm{SiH}_{4}$ ratio became higher, as shown in Figure 2. Incorporation of oxygen into the $\mathrm{Si} H \mathrm{H}$ network has a direct consequence for optical gap widening. A component of the increase in optical bandgap is associated with the $\mathrm{Si}-\mathrm{O}$ bonds because of the stronger bond energy of $\mathrm{Si}-\mathrm{O}$ compared to those of $\mathrm{Si}-\mathrm{Si}$ and $\mathrm{Si}-\mathrm{H}$ [18]. Addition of oxygen atoms to Si:H films can widen optical bandgap; however, the more the participation of the oxygen atoms, the lower the conductivity of the films, as indicated in Figure 3.

3.2. Characteristics of $a-S i O: H / \mu c-S i: H$ Micromorph Silicon Solar Cells. As shown in Figure 4, open circuit voltage $\left(V_{\mathrm{oc}}\right)$, short circuit current density $\left(J_{\mathrm{sc}}\right)$, and fill factor $(\mathrm{FF})$ 


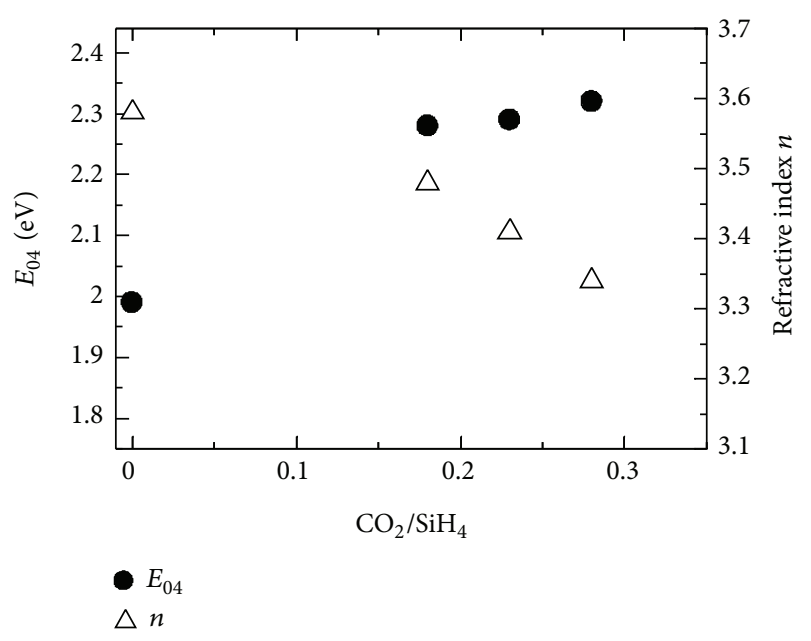

FIGURE 2: Optical bandgap $\left(E_{04}\right)$ and refractive index $(n)$ of $\mathrm{n} \mu \mathrm{c}$ $\mathrm{SiO}: \mathrm{H}$ films as a function of $\mathrm{CO}_{2} / \mathrm{SiH}_{2}$ ratio.

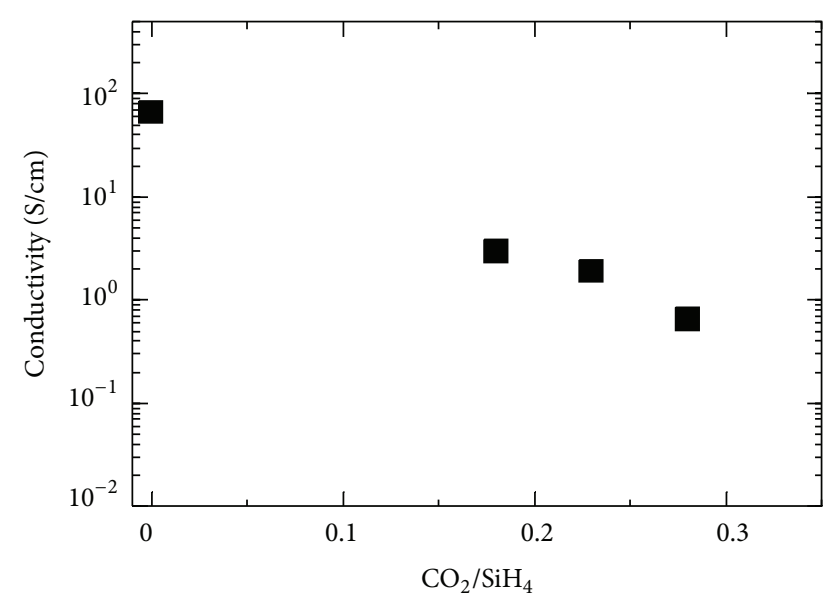

FIGURE 3: Dark conductivity of $\mathrm{n} \mu \mathrm{c}-\mathrm{SiO}: \mathrm{H}$ films as a function of $\mathrm{CO}_{2} / \mathrm{SiH}_{2}$ ratio.

of the solar cells obviously improved when the $\mathrm{n} \mu \mathrm{c}$-SiO:H film was applied as the $\mathrm{n}$ top layer instead of the $\mathrm{n} \mu \mathrm{c}-\mathrm{Si}: \mathrm{H}$ film $\left(\mathrm{CO}_{2} / \mathrm{SiH}_{4}=0\right)$. The best cell with initial conversion efficiency of $10.7 \%$ with $V_{\mathrm{oc}}=1.47 \mathrm{~V}, J_{\mathrm{sc}}=10.6 \mathrm{~mA} / \mathrm{m}^{2}$, and $\mathrm{FF}=0.67$ has been achieved at the $\mathrm{CO}_{2} / \mathrm{SiH}_{4}$ ratio of 0.23 , where the $X_{c}$ of the film was approximately $35 \%$. At the higher ratio, the $J_{\text {sc }}$ of the cell began to drop, resulting in a decrease in the cell efficiency. Since the $\mathrm{n} \mu \mathrm{c}-\mathrm{SiO}: \mathrm{H}$ films possess wide optical bandgap of about $2.3 \mathrm{eV}$ and higher defect density compared to the $\mathrm{n} \mu \mathrm{c}$-Si:H film, these are supposed to allow a better continuity of band diagram and also a better tunnel recombination junction at the connection between the top and the bottom cells. As mentioned previously, the i top and $\mathrm{p}$ bottom layers in these solar cells were wide bandgap $\mathrm{SiO}: \mathrm{H}$ based materials. The $E_{04}$ of the p bottom $\mu \mathrm{c}-\mathrm{SiO}: \mathrm{H}$ layer was estimated to be about $2.25 \mathrm{eV}$; thus the $\mathrm{n} \mu \mathrm{c}-\mathrm{SiO}: \mathrm{H}$ film with the $E_{04}$ of $2.3 \mathrm{eV}$ was probably better suited to the $\mathrm{n}$ top layer application for this cell structure. The enhancement in the $V_{\text {oc }}$ was supposed to be due to a reduction of reverse bias
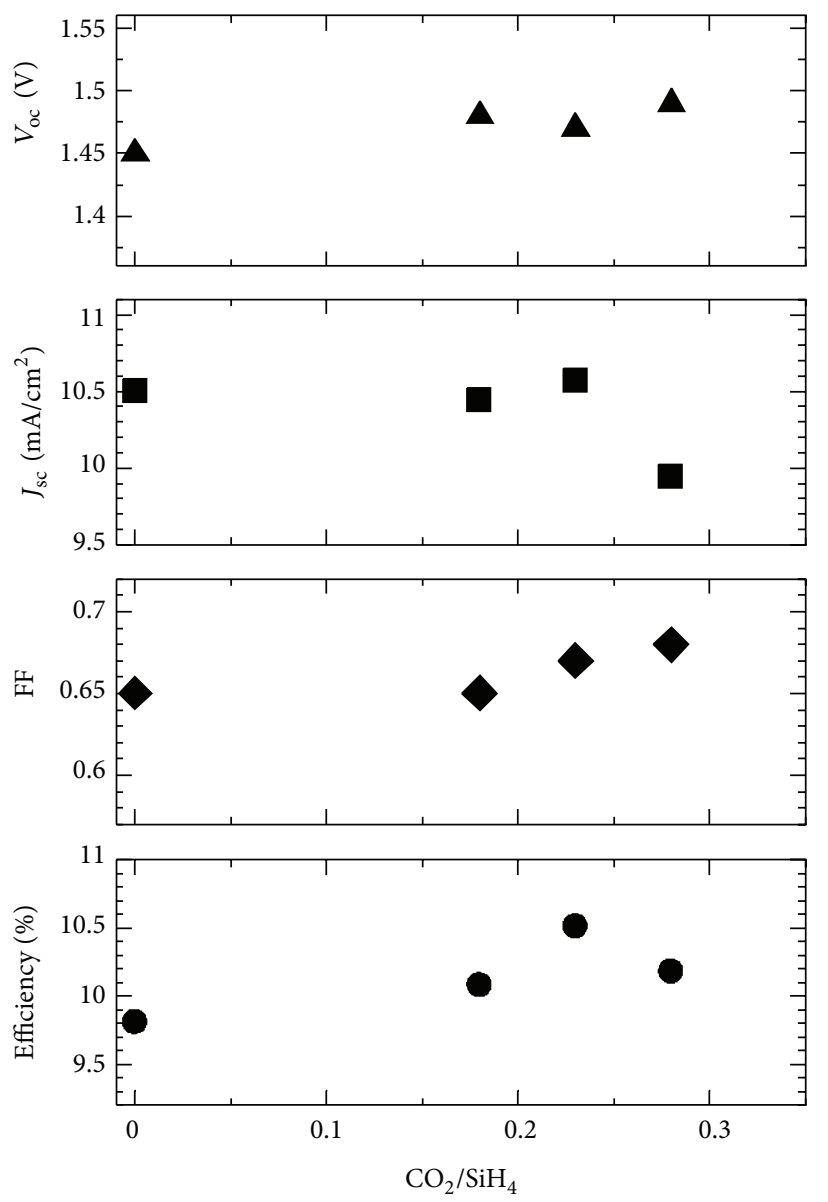

FIGURE 4: Photovoltaic parameters of a-SiO:H/ $\mu \mathrm{c}-\mathrm{Si}: \mathrm{H}$ micromorph silicon solar cells using $\mathrm{n}$ top $\mu \mathrm{c}-\mathrm{Si}(\mathrm{O}): \mathrm{H}$ layer deposited with various $\mathrm{CO}_{2} / \mathrm{SiH}_{2}$ ratios.

at subcell connection $-\mathrm{n}$ top/p bottom interface. The series resistance $\left(R_{s}\right)$ slightly increased while the shunt resistance $\left(R_{\text {sh }}\right)$ significantly enhanced from 1500 to $3200 \Omega$ when the $\mathrm{CO}_{2} / \mathrm{SiH}_{4}$ ratio increased from 0 to 0.28 , as shown in Figure 5. The increase of the $R_{\text {sh }}$ was supposed to be caused by the better tunnel recombination junction, contributing to the improvement in the FF.

According to the $\mathrm{QE}$ results shown in Figure 6, the spectrum response corresponding to the top a-SiO:H cell slightly enhanced while those of the bottom $\mu \mathrm{c}-\mathrm{Si}: \mathrm{H}$ cell decreased with increasing the $\mathrm{CO}_{2} / \mathrm{SiH}_{2}$ ratio. This suggested that, besides allowing ohmic and low resistive electrical connection between the two adjacent cells in the a-SiO:H/ $\mu \mathrm{c}-$ $\mathrm{Si}: \mathrm{H}$ micromorph silicon solar cell, the $\mathrm{n}$ top $\mu \mathrm{c}-\mathrm{SiO}: \mathrm{H}$ film also worked as an intermediate reflector to enhance light scattering, as verified by the increase of the spectrum response corresponding to the top cell. The drop of the $J_{\mathrm{sc}}$ at the $\mathrm{CO}_{2} / \mathrm{SiH}_{2}$ ratio of 0.28 was thought to be due to current mismatch between the top and the bottom cells.

Experimental results have verified the excellent multifunction of the $\mathrm{n} \mu \mathrm{c}-\mathrm{SiO}: \mathrm{H}$ films when they are applied in the a-SiO:H/ $\mu \mathrm{c}-\mathrm{Si}: \mathrm{H}$ micromorph solar cells, in addition to the conventional a-Si:H/ $\mu \mathrm{c}-\mathrm{Si}: \mathrm{H}$ structure. Interestingly, 

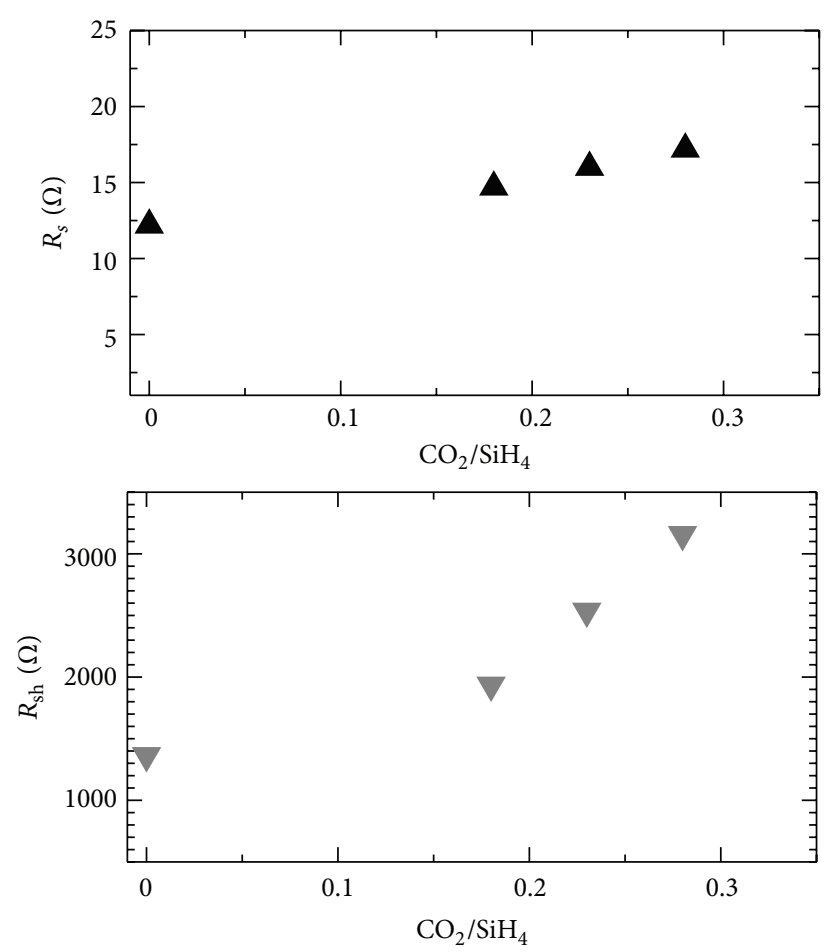

FIgURE 5: $R_{s}$ and $R_{\mathrm{sh}}$ of a-SiO:H/ $\mu \mathrm{c}-\mathrm{Si}: \mathrm{H}$ micromorph silicon solar cells using n top $\mu \mathrm{c}-\mathrm{Si}(\mathrm{O}): \mathrm{H}$ layer deposited with various $\mathrm{CO}_{2} / \mathrm{SiH}_{2}$ ratios.

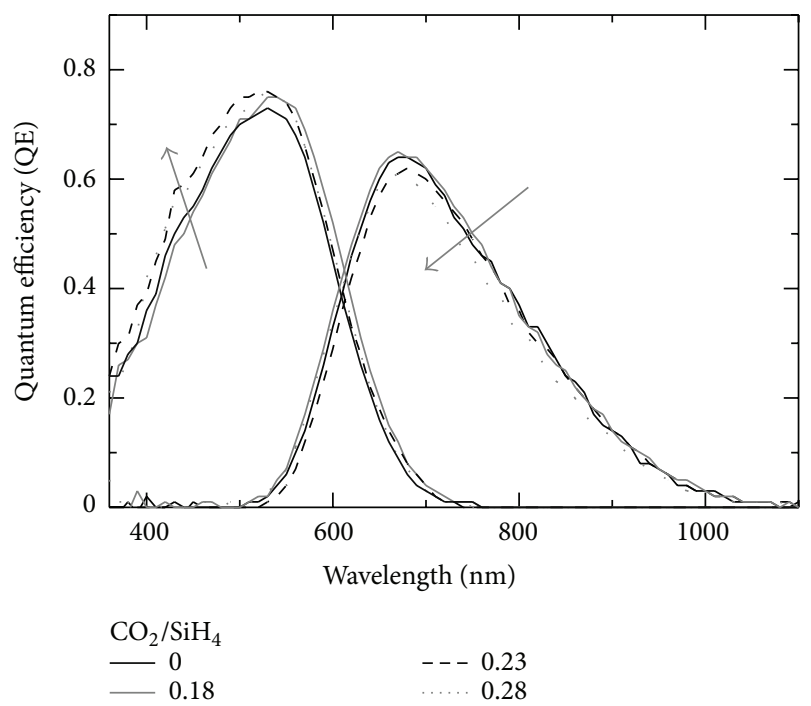

FIGURE 6: QE of a-SiO:H/ $\mu$ c-Si:H micromorph silicon solar cells using $\mathrm{n}$ top $\mu \mathrm{c}-\mathrm{Si}(\mathrm{O}): \mathrm{H}$ layer deposited with various $\mathrm{CO}_{2} / \mathrm{SiH}_{2}$ ratios.

the $V_{\text {oc }}$ of our a-SiO:H/ $\mu$ c-Si:H micromorph solar cells was found to be high, compared to the conventional micromorph solar cells [7-10], and was further improved when the $\mathrm{n}$ top $\mu \mathrm{c}-\mathrm{SiO}: \mathrm{H}$ layer was used. The $V_{\mathrm{oc}}$ of the conventional cells was about $1.38-1.42 \mathrm{~V}$, while the a-SiO:H/ $\mu$ c-Si solar cells showed the $V_{\text {oc }}$ as high as $1.47-1.49 \mathrm{~V}$. The multijunction thin film silicon solar cells with high $V_{\text {oc }}$ are considered to have advantage of low temperature coefficients (TC) [15]. Although, at present, the efficiency of the a-SiO:H/ $\mu \mathrm{c}-\mathrm{Si}$ micromorph solar cells is lower than that of the micromorph solar cells using conventional structure, their advantages are expected to become more obvious when the cells are operating in high-temperature environment.

\section{Conclusion}

We have developed the $\mathrm{n}$-type $\mu \mathrm{c}$-SiO:H films and applied them as the $\mathrm{n}$ top layer of the $\mathrm{a}-\mathrm{SiO}: \mathrm{H} / \mu \mathrm{c}-\mathrm{Si}: \mathrm{H}$ micromorph silicon solar cells. The solar cells using the $\mathrm{n}$ top $\mu \mathrm{c}-\mathrm{SiO}: \mathrm{H}$ layer showed higher $V_{\mathrm{oc}}, J_{\mathrm{sc}}$, and FF than the cell with the $\mathrm{n}$ top $\mu \mathrm{c}$-Si:H layer. Enhancements in the cell parameters were supposed to be due to the better tunnel recombination junction, the better continuity of band diagram at the subcell connection, and, equally importantly, the more efficient intermediate reflector, all of which were mainly owing to the $\mathrm{n} \mu \mathrm{c}-\mathrm{SiO}: \mathrm{H}$ films in the top cell.

\section{Acknowledgment}

This work was supported by Cluster and Program Management Office (CPM) of NSTDA, Thailand (P-00-10470).

\section{References}

[1] K. Haga and H. Watanabe, "Optical properties of plasmadeposited silicon-oxygen alloy films," Japanese Journal of Applied Physics, vol. 29, no. 4, pp. 636-639, 1990.

[2] Y. Matsumoto, F. Meléndez, and R. Asomoza, "Plasma CVD deposited p-type silicon oxide wide-bandgap material for solar cells," Solar Energy Materials and Solar Cells, vol. 52, no. 3-4, pp. 251-260, 1998.

[3] P. Buehlmann, J. Bailat, D. Domiń et al., "In situ silicon oxide based intermediate reflector for thin-film silicon micromorph solar cells," Applied Physics Letters, vol. 91, no. 14, Article ID 143505, 2007.

[4] Y. Matsumoto, V. Sánchez R., and A. Avila G., "Wide optical bandgap p-type $\mu \mathrm{c}-\mathrm{Si}: \mathrm{O}_{x}: \mathrm{H}$ prepared by Cat-CVD and comparisons to p-type $\mu \mathrm{c}$-Si:H," Thin Solid Films, vol. 516, no. 5, pp. 593596, 2008.

[5] Y. Matsumoto, F. Meléndez, and R. Asomoza, "Performance of p-type silicon-oxide windows in amorphous silicon solar cell," Solar Energy Materials and Solar Cells, vol. 66, no. 1-4, pp. 163170, 2001.

[6] A. Sarker and A. K. Barua, "Development of high quality p-type hydrogenated amorphous silicon oxide film and its use in improving the performance of single junction amorphous silicon solar cells," Japanese Journal of Applied Physics A, vol. 41, no. 2, pp. 765-769, 2002.

[7] P. Buehlmann, J. Bailat, D. Domiń et al., "In situ silicon oxide based intermediate reflector for thin-film silicon micromorph solar cells," Applied Physics Letters, vol. 91, no. 14, Article ID 143505, 2007.

[8] C. Das, A. Lambertz, J. Huepkes, W. Reetz, and F. Finger, "A constructive combination of antireflection and intermediatereflector layers for a-Si $\mu$ c-Si thin film solar cells," Applied Physics Letters, vol. 92, no. 5, Article ID 053509, 2008. 
[9] A. Lambertz, T. Grundler, and F. Finger, "Hydrogenated amorphous silicon oxide containing a microcrystalline silicon phase and usage as an intermediate reflector in thin-film silicon solar cells," Journal of Applied Physics, vol. 109, no. 11, Article ID 113109, 2011.

[10] V. Smirnov, A. Lambertz, B. Grootoonk, R. Carius, and F. Finger, "Microcrystalline silicon oxide $\left(\mu \mathrm{c}-\mathrm{SiO}_{x}: \mathrm{H}\right)$ alloys: a versatile material for application in thin film silicon single and tandem junction solar cells," Journal of Non-Crystalline Solids, vol. 358, no. 17, pp. 1954-1957, 2012.

[11] S. Kim, H. Lee, J. W. Chung, S. W. Ahn, and H. M. Lee, "n-type microcrystalline silicon oxide layer and its application to highperformance back reflectors in thin-film silicon solar cells," Current Applied Physics, vol. 13, pp. 743-747, 2013.

[12] K. Sriprapha, C. Piromjit, A. Limmanee, and J. Sritharathikhun, "Development of thin film amorphous silicon oxide/ microcrystalline silicon double-junction solar cells and their temperature dependence," Solar Energy Materials and Solar Cells, vol. 95, no. 1, pp. 115-118, 2011.

[13] K. Sriprapha, N. Sitthiphol, P. Sangkhawong, V. Sangsuwan, A. Limmanee, and J. Sritharathikhun, "P-Type hydrogenated silicon oxide thin film deposited near amorphous to microcrystalline phase transition and its application to solar cells," Current Applied Physics, vol. 11, no. 1, pp. S47-S49, 2011.

[14] J. Sritharathikhun, A. Moollakorn, T. Trakul, T. Krajangsang, A. Limmanee, and K. Sriprapha, "Optimization of $\mathrm{i}-\mathrm{a}-\mathrm{SiO}_{x}: \mathrm{H}$ absorber layer for thin film siliconsolar cells applications," Thin Solid Films. In press.

[15] K. Sriprapha et al., "Development of thin film a-SiO:H/a-Si:H double-junction solar cells and their temperature dependence," Thin Solid Films. In press.

[16] D. Das, M. Jana, and A. K. Barua, "Characterization of undoped $\mu \mathrm{c}$-SiO:H films prepared from $\left(\mathrm{SiH}_{4}+\mathrm{CO}_{2}+\mathrm{H}_{2}\right)$-plasma in $\mathrm{RF}$ glow discharge," Solar Energy Materials and Solar Cells, vol. 63, no. 3, pp. 285-297, 2000.

[17] H. Fujiwara, Spectroscopic Ellipsometry, Maruzen Publishing, Tokyo, Japan, 2003.

[18] A. Singh and E. A. Davis, "The a- $\mathrm{SiO}_{x}: \mathrm{H}_{y}$ thin film system I. Structural study by IR spectroscopy," Journal of Non-Crystalline Solids, vol. 122, no. 3, pp. 223-232, 1990. 

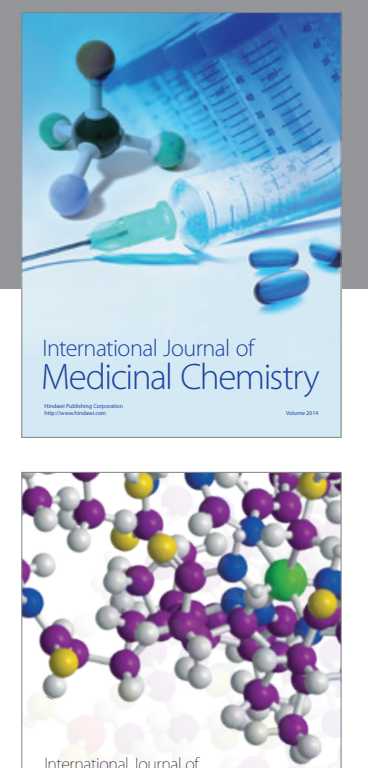

\section{Carbohydrate} Chemistry

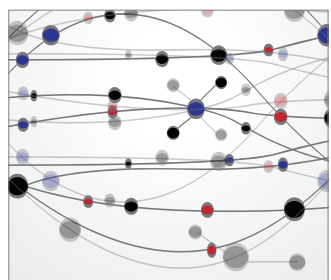

The Scientific World Journal
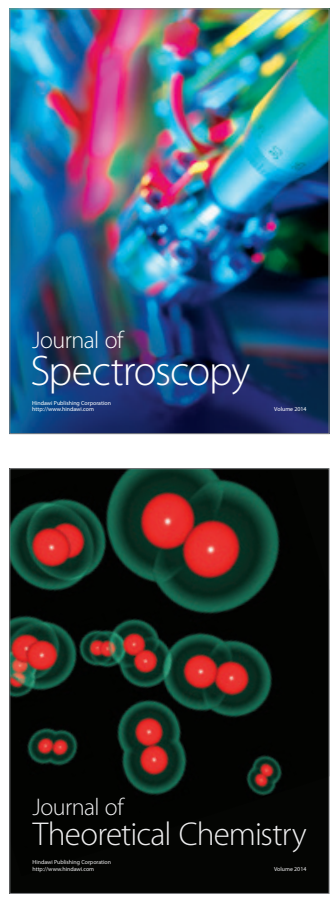
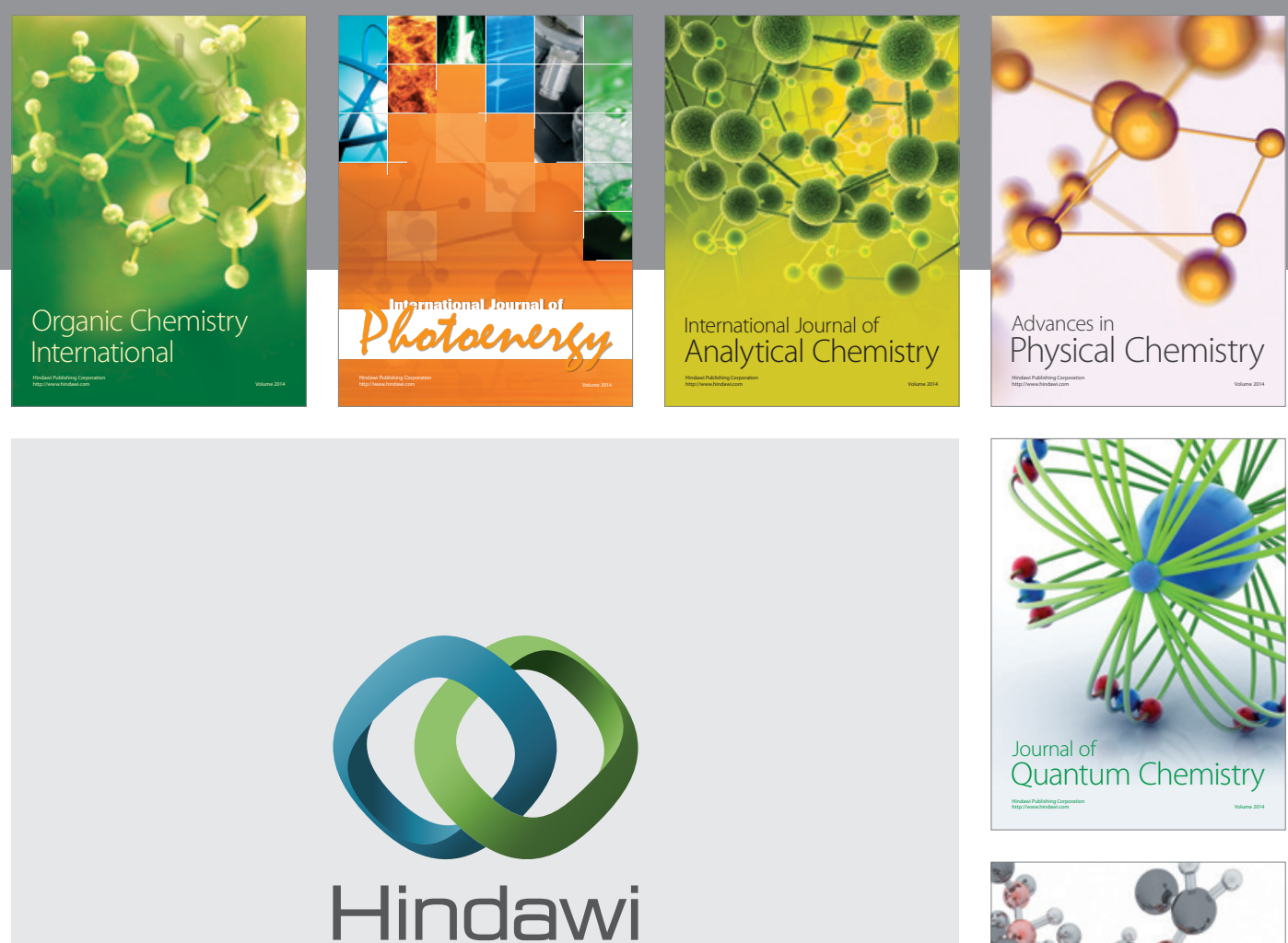

Submit your manuscripts at

http://www.hindawi.com

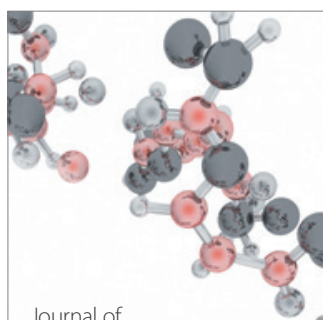

Analytical Methods

in Chemistry

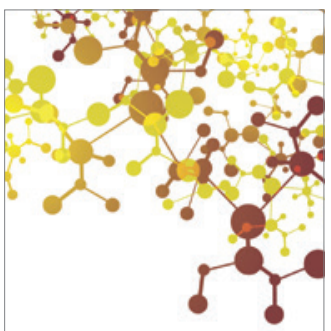

Journal of

Applied Chemistry

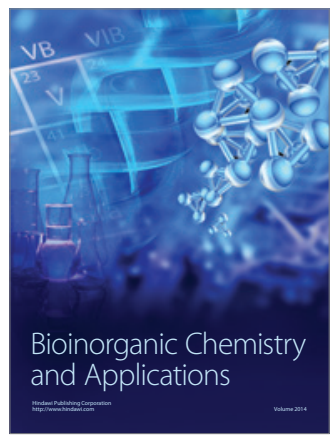

Inorganic Chemistry
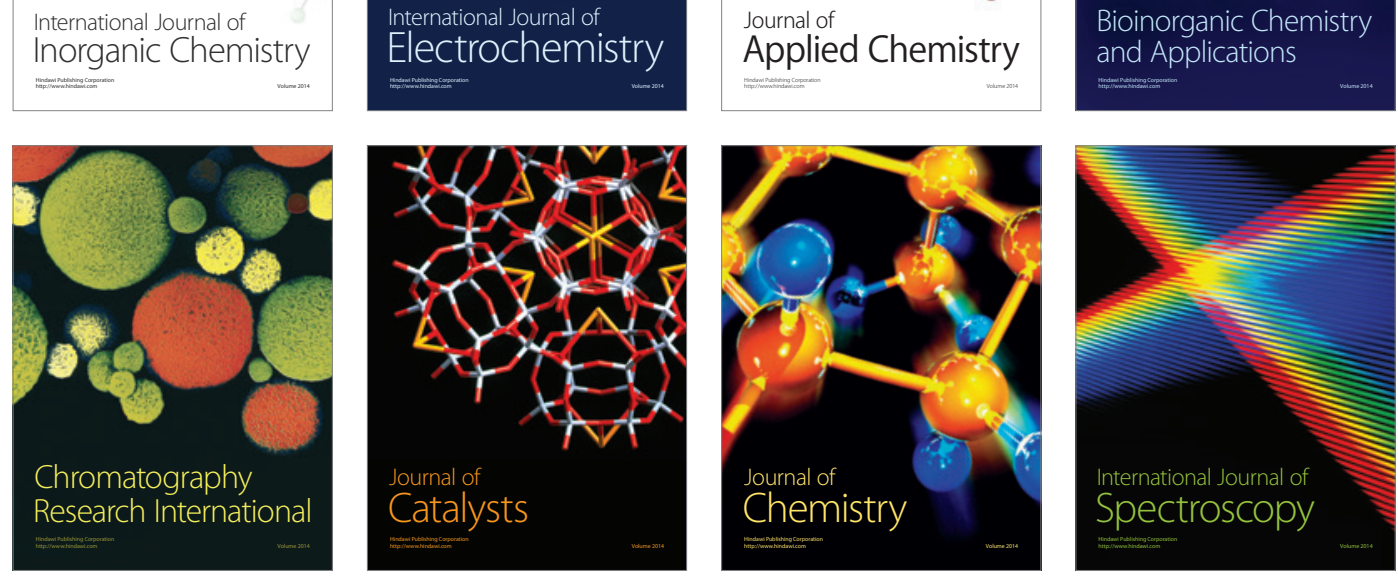